\title{
The Peacock versus the louse (pediculus humanus corporis): one soldier's contribution to combating trench fever in the First World War
}

\author{
${ }^{1} \mathrm{~A}$ Peacock, ${ }^{2} \mathrm{~W}$ Pearson \\ ${ }^{1}$ Honorary Research Professor in Public Finance, Edinburgh Business School, Heriot-Watt University, Edinburgh; ${ }^{2}$ Formerly Chief Librarian \\ Milton Keynes Council, Buckinghamshire
}

\begin{abstract}
Trench fever became a major worry for the Allied High Command during the First World War because of its debilitating effects on troop performance. The causes of the fever were not previously known, but entomological research identified the body louse (pediculus humanus corporis) as the carrier, and the Royal Army Medical Corps developed effective methods of control through disinfestation. These were markedly influenced by the researches of a young entomologist, Alexander David Peacock, which were conducted under campaign conditions. Peacock subsequently occupied a Chair of Zoology at St Andrews University for 30 years.
\end{abstract}

KEYWORDS Body louse, disease vectors, disinfestation, entomological research, Alexander David Peacock, Royal Army Medical Corps

DECLARATION OF INTERESTS Sir Alan Peacock is the son and William Pearson the grandson of Alexander David Peacock.

\section{INTRODUCTION}

By the end of 1914 the formidable attack of the German Army had been halted by British and French troops, but the Allied High Command had little option but to order the British Expeditionary Force (BEF) to 'dig in' alongside their French Allies. The Western Front was established with a large proportion of the frontline troops accommodated in narrow trenches in which, from 1915 on, they had to live and from which they launched into battle. This provided a challenge for the Royal Army Medical Corps (RAMC), for as well as trying to restore the fighting strength of the wounded they had to face the prospect of illness resulting from unhygienic living conditions. Of particular concern to the RAMC was the discovery that an illness, later identified as 'trench fever', was spreading among British troops. The progress of the disease, its severity and epidemiology all had to be established before the RAMC could present evidence to the High Command that it could represent a serious threat to the conduct of the war. One estimate put the number of Allied troops affected at 800,000 ,' while another study estimated that trench fever accounted for some $20 \%$ of soldiers admitted to casualty clearing stations. ${ }^{2}$ A more recent analysis has suggested slightly lower figures. ${ }^{3}$

During the early stages of the First World War, this concern did not appear to be shared by the High Command, whose 'success indicator' was the ground gained by counter-attack and which kept armies on the move. If success was to be guaranteed within a few weeks, investing in better living conditions in what would only be temporary accommodation was considered a waste of
Correspondence to Sir Alan Peacock, 5/24 Oswald Road, Edinburgh EH9 2HE, UK

tel. +44 (0) I3। 6675677

resources. The history of what subsequently happened is too well known to need repeating. What is relevant here is that for nearly three years trench warfare became an integral part of frontline operations, making 'digging in' to provide accommodation a primitive necessity. ${ }^{4}$

The early investigations into trench fever confirmed that it was caused by an unpleasant, insect-borne infection, the vector being the body louse (pediculus humanus corporis). But much more had to be learnt about the disease to enable the RAMC to advise the BEF on prevention and treatment. An important discovery was that, unlike typhus, trench fever was rarely fatal. But how long would an affected soldier be out of action? Would affected troops be able to resume their previous duties? What changes would be needed in the facilities for controlling the incidence of the disease?

The aims of this paper are to describe the role of the investigations of the entomologist Alexander Peacock in providing the answers to these and other relevant questions. Peacock is still remembered by erstwhile medical students as the Professor of Natural History at University College, Dundee, University of St Andrews (1926-1956). In the First World War he served in the RAMC from 1915 to 1919 (Figure I), beginning as a stretcher-bearer on the Western Front and ending up as a captain.

This article has two subsidiary aims. The first is to use papers from Peacock's archive ${ }^{5}$ (which have only recently been discovered by the authors) to support the case for a wider interpretation of his professional contribution to the study of insect-borne diseases generally and to trench 
fever in particular. While the authors are not in a position to assess his contribution to entomology, his personal and professional history tells us much about the problems encountered in achieving compatibility between 'the world of the microscope and that of the stethoscope'. ${ }^{6}$

A further aim is to give an illustration of the difficulties that arise when scientific discoveries point towards major changes in the relative importance of methods for prosecuting a war. In the First World War, scientific investigation not only implied access to technical resources but also a commitment to the recruitment of specialised manpower. For example, proposals for controlling disease, if accepted, entailed additional resources to improve cleanliness and medication. Peacock's unusual army career manifests the complexity of these changes, highlighting the difficulties encountered by the RAMC in persuading the High Command to confer on him the necessary status to have his scientific work recognised.

\section{ALEXANDER PEACOCK: BIOGRAPHY}

Alexander David Peacock (1886-1976) was born in Newcastle upon Tyne, the son of a grocer with a literary bent who had a stall in the Bigg Market. ${ }^{7}$ From his maternal forebears, Tyneside wherrymen, he inherited his smallish build and vitality. Educated initially at a Board School, he obtained a scholarship to Newcastle upon Tyne Grammar School when he was 13 years old, but had to leave after two years to help in his father's business. Peacock then attended evening classes in commerce and art with the intention of becoming a shipping clerk or possibly a commercial artist. Instead, he became a pupil teacher, qualified to attend Durham University (Armstrong College, Newcastle) with his fees covered by a Board of Education grant, conditional on taking service on graduation in an officially recognised educational institution. He combined compulsory study of teaching practice with zoology as his principal subject. In his own words (extracted from his obituary), he "became a keen Darwinian, went "left" and affected unorthodox headgear'. (The combination of the acceptance of Darwinism, radical politics and some element of eccentricity was a common feature among pioneering Victorian entomologists. ${ }^{8}$ )

Peacock became an entomologist by a fortunate chance. After graduation, he taught in a Council school in Jarrow and gave evening classes on elementary physics to shipyard apprentices (who, after a ten-hour day, often fell asleep while being taught). Eighteen months later he was appointed a student demonstrator in zoology, 'passing rich on $£ 60$ per annum'. In order to consolidate his research interests he obtained a grant to attend courses at the Royal College of Science and the Natural History Museum. The staff in both institutions were clearly impressed with Peacock's knowledge and dedication,

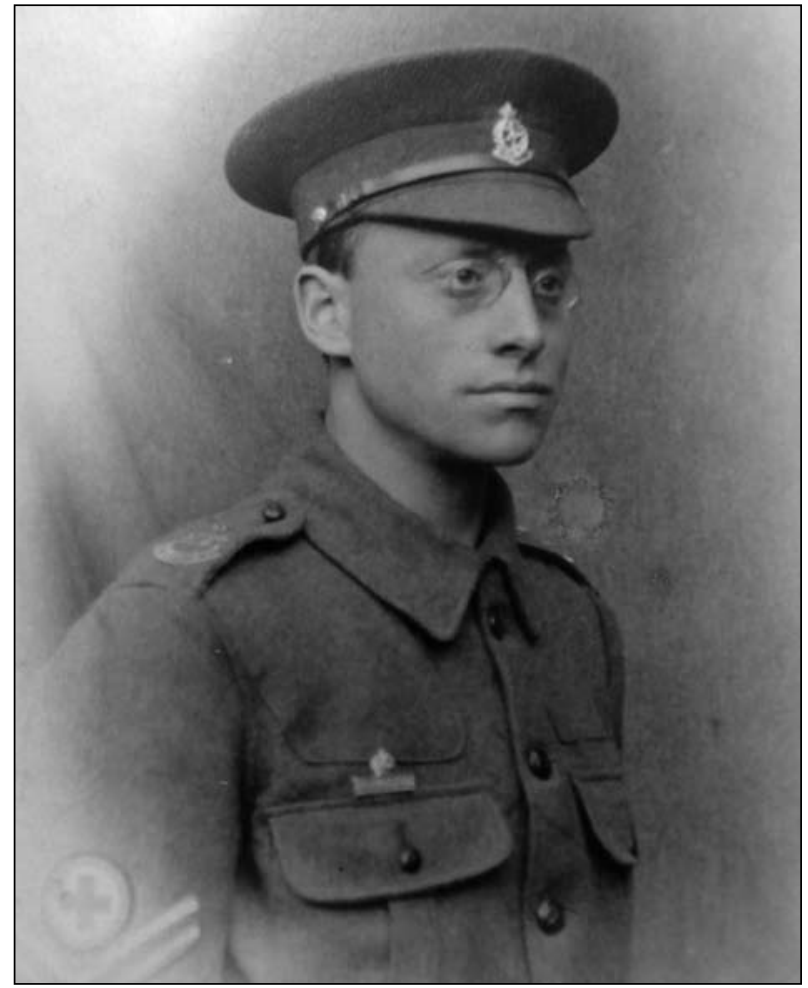

FIGURE I Alexander Peacock served in the RAMC from 1915 to 1919. (Authors' collection.)

and in 1911 he was recommended for an appointment as entomologist in the Southern Nigerian Agricultural Department by Harold Maxwell Lefroy, later Professor of Entomology at Imperial College and founder of the Rentokil company. Armed only with a letter of advice from Patrick Manson, founder of the School of Tropical Medicine in London, Peacock found himself engaged in investigating the habits of the major health scourge of West Africa, the mosquito, the notorious carrier of the malaria parasite. His investigations led him to an experiment in self-infection, as a result of which he contracted malaria. After one tour of service he came home to convalesce.

During convalescence he wrote up his experiences in the form of a paper ${ }^{9}$ for which he was awarded the degree of MSc, and in 1913 he returned to Armstrong College as lecturer in zoology. War was declared the following year and in September 1914 he volunteered, being advised that in view of his service in the University's Officers' Training Corps, he should apply for a commission.

\section{THE LOUSE PROBLEM AT THE FRONT}

In late 1915, the officers of a battalion of frontline troops, the 6th Royal Scots Fusiliers (RSF), were far from pleased when they had word about their next colonelin-charge. They had just said goodbye to a popular colonel who had led them through difficult days in battle. When he first met his officers, the new colonel simply announced: 'War is declared, gentlemen... on the louse.' 
This was followed by a learned discourse on the influence of insects on the course of military history, ending with a detailed analysis of the louse and ways of getting rid of it. He called on medical staff to prepare methods of disinfestation and asked the French liaison officer, Herzog (who achieved literary pre-eminence after the war, writing as André Maurois), to seek out baths for the men in the nearest town. It was claimed that after four days of intensive work the colonel was able to announce that 'a triumphant victory had been won' and the 6th RSF claimed to be a louseless battalion. This rather unorthodox approach to winning over his men, followed by further examples, was highly successful during the relatively short time that the colonel remained in Army service. This unusual officer was none other than Winston Churchill. ${ }^{10}$

The relevance of this incident lies in the fact that Churchill had introduced himself in this unorthodox fashion as early as January 1916, suggesting that he had been made aware of the louse problem by the BEF medical staff of the RAMC before taking up his post. Another possible explanation is that Churchill recalled methods already used during the Boer War by the RAMC and ancillary civilian hospital staff, which concentrated on the importance of personal hygiene among troops.

Scientific research had been undertaken at Cambridge by the pioneer entomologist Arthur Shipley and colleagues into the habits of the louse which, in his words, played 'a large part in the minor discomforts of an army'." Much of Shipley's analysis was based on reports of insect infestation during the Boer War. Shipley's colleague, Cecil Warburton, conducted controlled experiments to study male and female lice in detail and particularly their breeding habits, length of life and parasitic feeding arrangements, in which they were given access to human skin. Shipley and his colleagues found rearing lice difficult. 'If you want them to live they die,' Shipley wrote, 'and when you want them to die they live, and multiply exceedingly."

Peacock's first investigations into trench fever are known to have been nearing completion about the time of Churchill's posting to the RSF, and were first published in July 1916. ${ }^{2}$ These were issued as a Crown Pamphlet, which was distributed throughout the BEF. It is therefore highly unlikely that his practical proposals would have reached Churchill's ears before this posting. (Peacock was certainly aware of the Cambridge experiments, which are mentioned in his pamphlet.)

This does not detract from the pioneering character of Peacock's research. In the first place, the pre-war reason for the efforts to rid the troops of lice was because of the fear of typhus fever caused by the louse's passion for human blood. Subsequent analysis of the epidemiology of trench fever confirms that only during the First World War was the unique relation between the louse's habits and the incidence of the fever firmly established. In particular, Peacock's researches were among the first to emphasise the louse as the vector of the disease, not only infecting soldiers by biting but also through contact between its faeces and the marks left on human skin from scratching.'

In the second place, whereas the Cambridge investigations were conducted according to the conventions of laboratory research and were primarily directed at the life cycle of the louse, Peacock was conducting his research under actual frontline conditions and with the practical objective of establishing the influence of the louse on the fitness of troops under orders to fight. Whatever the obvious disadvantages of conducting research at the frontline, this had the advantage of direct observation of the interplay between the louse and his 'victim', the infested soldier.

Thirdly, while both the Cambridge and RAMC war investigations had the purpose of adding to scientific knowledge, the latter were expected to yield practical results, some of which could only be carried out by additional claims on regimental resources. In other words, the value of any research findings and the consequential additional demand for resources or resource reallocation must have had to be weighed against the value of their alternative use - more hospital beds and baths or more conscripts? The RAMC was not in a position to decide on such matters, and its top brass had to be convinced that, at the margin, more scientists were a better bet than more stretcher-bearers. These considerations are reflected in Peacock's later military career.

\section{PEACOCK'S WARTIME INVESTIGATIONS}

Peacock was not called to service until March 1915, when he became a private in the RAMC attached to his 'home' regiment, the First Northumberland Fusiliers. It is not recorded in any form how he was extracted from the front as a member of a field ambulance unit and promoted first to corporal (Figure I) and then to lance-sergeant when he was assigned to trench fever investigation in the autumn of 1915 .

Peacock's investigations are recorded in his experimental diary, his personal diary and his reports. ${ }^{5}$ The results of his six months of experimental work under campaign conditions were published as 'The Louse Problem at the Western Front' in The Journal of the Royal Army Medical Corps in July 1916.'2 As already mentioned, the article was reprinted as a Crown Pamphlet. It was deliberately written in as non-technical a form as possible.

Peacock's 1916 article indicates that his promotion was made after 'some months' and would give him the authority, with the permission of his senior officer, 
possibly Captain McNee, RAMC, to study the louse problem 'under campaign conditions', with which Peacock was by now fully familiar. McNee is acknowledged on the first page of Peacock's article for offering facilities for his work. In the previous number of The Journal of the Royal Army Medical Corps McNee, together with JW Renshaw and $\mathrm{EH}$ Blunt, published an article on the characteristics of trench fever ${ }^{13}$ but left open the question as to whether the principal vector was the louse. Although neither McNee nor Peacock refers to the other's work, their studies complement one another, and Peacock emerges as the first researcher under campaign conditions to establish the louse as the vector.

The first section of his article is a full description of the morphology of the louse, covering its external and internal physical characteristics, as a necessary precondition for examining its behaviour. This would normally be done by clear delineation of its 'moving parts' in drawings. No previous drawings meeting this requirement were known to exist, so Peacock's first innovation was to prepare these himself (Figure 2). We judge this as the work of a trained artist, and recall his one-time intention of becoming a commercial draughtsman. He later published an even more detailed description of the morphology of the louse. ${ }^{14}$

The second section offers a detailed analysis of the habits and instincts of the louse. Its conclusion reads: 'The louse... is a parasite that is utterly dependent upon a man's blood for sustenance and man's body and clothing for prolonged, prosperous longevity and reproduction.' ${ }^{\prime 2}$ The conclusion became recognised as an advance in knowledge. Space prevents a description of the habitat, alimentation, life history and vitality, which were examined in detail. Crucial to the understanding of the louse was that 'the insect accumulates where there is plenty of warmth, plenty of humidity and plenty of shelter.'.2 Furthermore, 'they are expert at digging in among the seams of clothing to which lice strongly adhere by hooked claws. Favoured sites are creases at the back of shirts and seams at the fork of breeches.'2

The second part of this section reveals the true extent of the courage and skill necessary to arrive at concrete results. Detecting where the lice were located, the influence of location on their prevalence, whether the nature of the various duties of soldiers influenced their presence - these were some of the factors that would determine what Peacock labelled 'the degree of lousiness' and would have a pronounced bearing on attempts made to control the incidence and severity of discomfort and disease. ${ }^{12}$

Most of the data had to be supplied by the individual troops themselves, and reliable results depended on their incentive to co-operate. 'Self-searching' for pests, counting them on a daily basis, might have seemed a superfluous

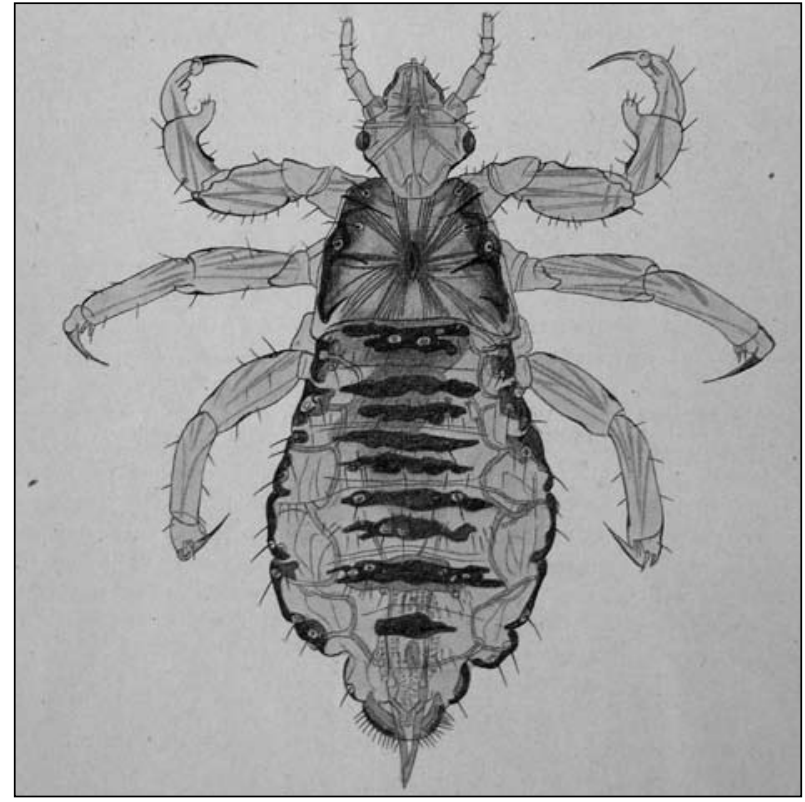

FIGURE 2 An illustration of the louse, drawn by Peacock himself, from his 1916 paper. ${ }^{12}$ It the first of four drawings of this kind covering the characteristics of both male and female lice externally and internally.

chore to those living in trenches and dugouts for whom battle conditions brought to mind more important sources of misery. It is true that under wartime conditions troops could simply be ordered to co-operate, but whatever effect this might have on the response rate it hardly guaranteed the reliability of the results.

In seeking to influence the degree of co-operation, Peacock had two advantages. His pre-research days in the RAMC spent as a stretcher-bearer meant that he had experienced battle conditions himself, and had remained a 'ranker' like his subjects. His natural sympathy with his fellow soldiers was expressed in his 1916 article: 'Lousiness is felt mostly at night... Probably the distractions of the day keep the mind away from the pest, but at night... the mind is most sensitive to the slightest irritation.'2 Peacock was also willing to become part of his own subject matter, for he and a volunteer stretcher-bearer tested some of their results by selfinfection. An unusual and amusing piece of evidence showing that Peacock's efforts were understood and commanded support is provided by a cheerful set of cartoons of the 'louse-hunter' (Figure 3). The cartoons were drawn by 'H Gibson'.

From the evidence provided, Peacock sought to identify the verminous condition of the men, which he did for a sample of 274 cases. He invented the concept of 'the degree of lousiness' to enable him to measure the differential liability of different units to infection and their risk of contracting trench fever. This concept of the degree of lousiness led him to a careful analysis of the concentration of lice in different items of clothing and in different fighting units, the men of whom lived and worked 


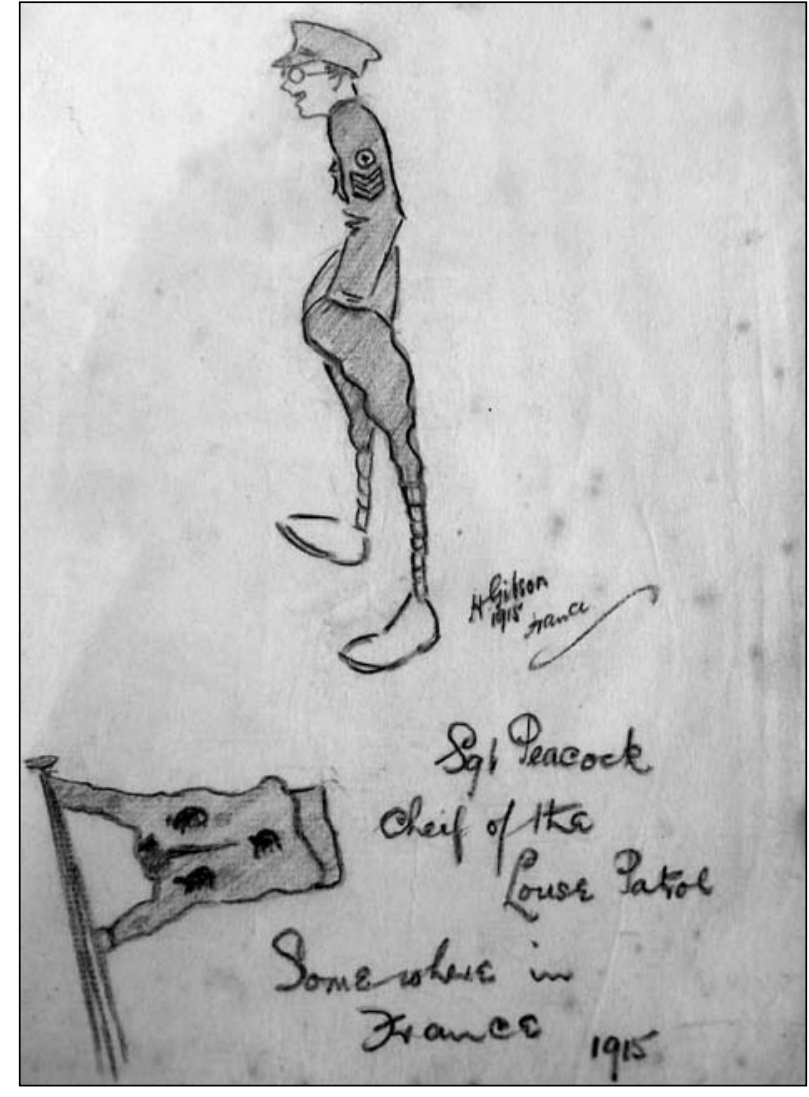

FIGURE 3 A wartime cartoon by 'H Gibson' depicting Peacock as 'Chief of the Louse Patrol'. (Authors' collection.)

under different conditions. These 'refinements' were important in working out methods for getting rid of lice.

The degree of lousiness was a function of the concentration of men according to their living quarters, but other influences were significant, such as the frequency of bathing and the nature of their tasks. Thus the sample of 274 infantrymen of Peacock's division showed a lousiness of 20 lice per man after six months on the battle line, with a variation of between 10 and $30 .^{12}$

These data were broken down into various units. The average of the 33 cyclists living in billets was II lice per man, and 20 artillery men also living in billets showed the low average of 3.5 lice per man. Peacock was particularly interested in the case of railway engineers for not a single louse was found on them! He attributed this mainly to their work, which involved using oil that repelled lice.

Not content with analysing the habits of the louse, Peacock extended his enquiries to possible methods of reducing the incidence of trench fever. ${ }^{15} \mathrm{He}$ was eminently qualified to do so in respect of measures that relied on the RAMC's long experience in the promotion of hygiene as a deterrent of disease. If anything, these measures were more important in the case of trench fever, given that no vaccine had been developed as a

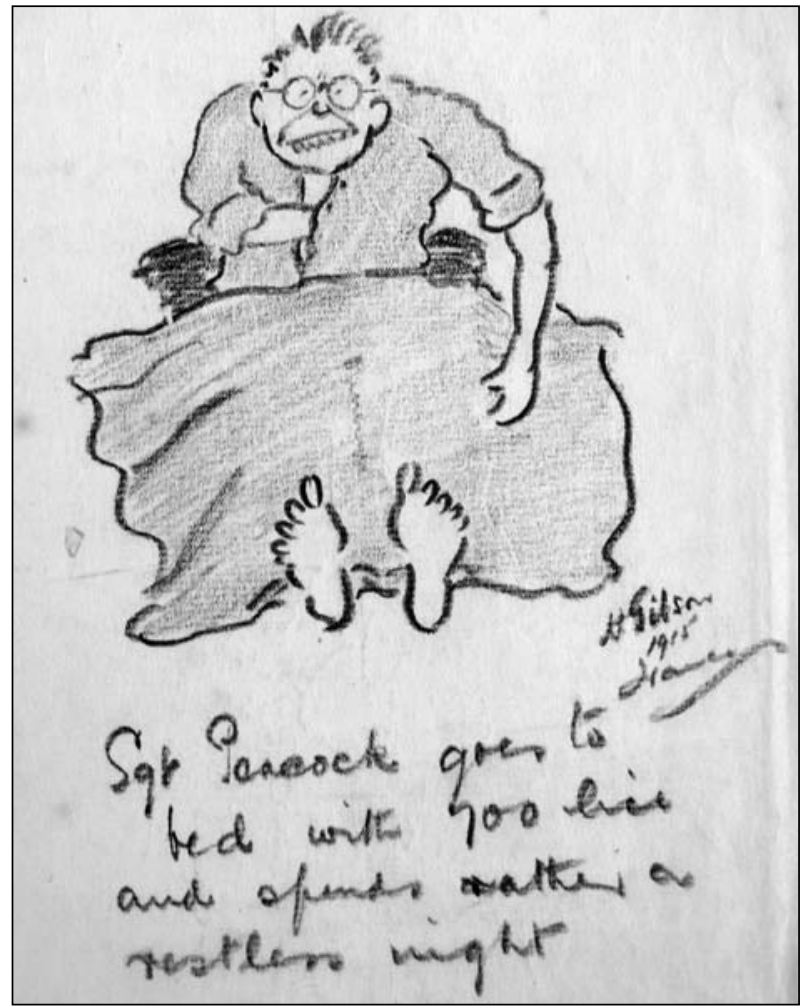

FIGURE 4 Peacock used himself as an experimental subject, 'going to bed' with 700 lice. (Authors' collection.)

means of prevention. Having concluded that 'once the louse was brought to the Expeditionary Force, the absence of facilities for washing and changing clothing, and the crowding together of troops, gave the parasite every condition favourable to lodging, feeding, multiplying and spreading,, ${ }^{2}$ Peacock set to work to offer suggestions for changes in hygiene control. His main modification of existing arrangements was to emphasise the importance of ironing as well as washing clothing, and to invent a scheme for improving the logistics of combining bathing, washing and ironing.

A final example of his experimental thoroughness is found in his testing of insecticides as a means for reducing the louse population. Peacock favoured naphthalene, creosote and iodoform $(\mathrm{NCl})$ in powder form. He scattered 700 lice in a sleeping bag (Figure 4) and smeared the preparation on a shirt and riding breeches at the fork and down to the knees. Socks instead of puttees were worn, allowing more freedom of access for lice. Next morning, no lice were found on the smeared parts, but 155 dead lice were shaken from the socks and 30 below the knees of the breeches. Figure 4 reveals the 'victim' as Peacock himself! However, $\mathrm{NCl}$, particularly at the fork, causes severe smarting and, as an alternative, an ointment insecticide was recommended in this region. The first choice was vermijelli which, interestingly enough, was based on the advice of Maxwell Lefroy. One unfortunate personal result of selfexperimentation was that Peacock had an attack of trench fever, but fortunately no recurrence. 
Peacock had one last self-imposed task. It was one thing to show, after research under very unfavourable conditions, what were the essential measures that would constitute a plan of campaign of prevention, but it was another to design concrete proposals. This was to be at the forefront of his mind in his subsequent career in the RAMC.

\section{THE RELUCTANT ACCEPTANCE OF 'EXPERIMENTAL MEDICINE'}

One of the results, substantiated by the considerable number of papers that were spawned out of Peacock's work, was the greater prominence given to the role of research as an integral part of the war effort. However, in the case of the RAMC this prominence was limited. What commanded public and military attention were the acts of heroism of medical staff who went out into the field to rescue casualties, and the dramatic portrayal of the methods used by surgeons to patch up the wounded. The RAMC, as with all specialist units, had to work within resource constraints. Difficult decisions had to be taken about the relative contribution of medical services in maintaining the quality of manpower on the one hand and the pursuit of research on the other. While the results of the former were easily understood as vital to the conduct of war, the latter could only yield results in the longer term, and its outcome might be uncertain.

These considerations are reflected in the subsequent career of Peacock in the RAMC. The case for referring back to his original request to become an officer became crystal clear. The direction of research, in which he was eminently qualified, was already the task of specialist officers. His work had become widely known throughout the RAMC through his Crown Pamphlet, itself an indication of the importance attached to it. After the usual administrative delays, in mid-January 1917, the Director of Medical Services of the 2nd Army recommended him for a commission; the request for promotion was sent to the High Command and to the Director of Medical Services for the BEF. ${ }^{16}$

It took from January until May for the request to be considered and granted. Objections were raised at senior levels. The first was that he was not a trained doctor. Although veterinary surgeons and those with qualifications in 'sanitary science' had been granted commissions, entomologists had not. When it was admitted that entomology was a necessary skill in RAMC research work, the reply was that no positions were available. The persistence of the Director of Medical Services of the 2nd Army won the day, and in May 1917 Peacock was commissioned as a Lieutenant RAMC in the London Sanitary Corps.

However, 'sanitary duties' were not to be his concern. The entry of the Americans into the war in 1917 brought with it a high-powered team of medical researchers who, with the full backing of the American High Command, requested (and obtained), from Field Marshall Haig himself, permission to conduct experiments on the incidence of trench fever with the help of British staff and BEF hospital facilities. Peacock's work was already known to the American team. This enabled Peacock to continue giving service by working in areas in which he had a comparative advantage. Peacock became a member of the American Trench Fever Commission in January 1918, and shortly after was promoted to captain. The report of the commission, published by Oxford University Press on behalf of the American Red Cross Society, became one of the major sources of information on the causes of and remedies for trench fever. ${ }^{17}$ After the war the infective agent was found to be Rickettsia quintana (so-called because trench fever typically had a five-day period of fever).

\section{CONCLUSION}

Historians in the past harboured the suspicion that entomology, originally the accidental discovery of nineteenth-century dilettante intellectuals in the leisured classes, owed its official recognition to the imperialist ambitions of successive British governments. Hence the charge that the eradication of insect-carrying diseases was primarily designed to prevent illness among only the ruling classes and those who served them. Recent investigations suggest that such a view is a considerable oversimplification. ${ }^{8}$ Furthermore, whatever view is taken of the stimulus given to entomological research by imperialism, its practical results during the First World War were a rapid growth of public awareness of the benefits resulting from preventative medicine based on entomological research. After the war Peacock was awarded the degree of DSc for his research, and in 1926 appointed to the chair of Natural History at University College, Dundee, University of St Andrews. In that year he became a Fellow of the Royal Society of Edinburgh and in 1955 was awarded its Keith Prize for his original research on parthenogenesis in insects.

Peacock won his spurs as a researcher while a colonial civil servant in Nigeria, but his very origins and his perception of what he hoped to do to help the ordinary soldier ${ }^{12}$ were a pointer towards his fulfilment of a much wider mission in his professional life. This also entailed continuing and close contact with medical colleagues. The best evidence of this is a book co-authored with RC Garry, his fellow professor at Dundee who later became Professor of Physiology at Glasgow. ${ }^{18}$ It is another pioneering effort, based on the first course of lectures for schools on biology broadcast by the BBC in the 1930s. Complete with illustrations, many drawn by Peacock, it was included in pamphlets issued to participating schools. Two chapters are devoted to insects and the passage of disease, which could only have been written by a scientist with a unique knowledge of entomology. 
Typical of those who had undergone the horrors of the trenches in the First World War, Peacock never talked and rarely wrote about his personal experiences.

\section{Acknowledgements}

The authors acknowledge their indebtedness to the following persons and institutions who have helped them prepare this contribution:Tyne and Wear Archives Service; Simon Blundell, Librarian of the Reform Club, London; lain Milne and Estela Dukan, Librarian and Assistant Librarian, Royal College of Physicians of
Edinburgh; Dr Colin Currie, Fellow of the Royal College of Physicians of Edinburgh; Dr John Clark, Director, Institute for Environmental History, University of St Andrews; and Connie Paton, Edinburgh Business School, Heriot-Watt University. A special word of thanks is due to Professor Nick Bosanquet, lately Professor of Health Service Policy, Imperial College, London, for drawing our attention to the current interest in Alexander Peacock's role in combating trench fever in the First World War, as well as for drawing our attention to source material.

\section{REFERENCES}

I W Byam, L Lloyd. Trench fever: its epidemiology and endemiology. Proc R Soc Med 1920; I3:1-27.

2 Prevention of infestation by lice. In: Macpherson WG, editor. History of the Great War based on official documents by direction of the Historical Section of the Committee of Imperial Defence. Medical services: general history. Vol. II. London: Macmillan; 1923. p. 327.

3 RL Atenstaedt. Trench fever: the British medical response in the Great War.J R Soc Med 2006; 99:564-8. doi:I0.1258/jrsm.99.I I.564

4 General staff. Notes of infantry officers on trench warfare. London: HMSO; 1916.

5 Tyne and Wear Archive Services Collection: Captain Alexander David Peacock, RAMC. Ref DX250.

6 Bynum W. The history of medicine: a very short introduction. Oxford: Oxford University Press; 2008. p. 91-1 17, 136-8.

7 Obituary notice: Alexander David Peacock. Proc $R$ Soc Edinb 1976-77. p. 47-50.

8 Clark JFM. Bugs and the Victorians. New Haven: Yale University Press; 2009. p. I87-2I5.

9 Peacock AD. Entomological pests and problems of Southern Nigeria. Bull Entomol Res 1913; 4:191-220.

10 Gibb AD. With Winston Churchill at the front. Glasgow: Cowans \& Gray; 1924. p. 21-3.

II Shipley AF. The minor horrors of war. London: Smith, Elder \& Co; 1915.

12 Peacock AD. The louse problem at the Western front. J R Army Med Corps 1916; 27:31-60.

I3 McNee JW, Renshaw A, Brunt EH. 'Trench fever': a relapsing fever occurring with the British forces in France. Br Med J 1916; 1:22534. doi:I0.II36/bmj.I.2876.225

14 Peacock AD. The structure of the mouthparts and mechanism of feeding in Pediculus humanus. Parasitology 1918; II:98-II7. doi:I0.1017/S003II82000004I2I

I5 Tyne and Wear Archive Services Collection: Captain Alexander David Peacock, RAMC. Ref DX250/I7.

16 National Archives. RefWO 374, 52888, 372333.

17 Strong RP, editor. Trench fever. Report of Commission, Medical Research Committee, American Red Cross. Oxford: Oxford University Press; 1918.

I8 Garry RC, Peacock AD. Living and learning: an introduction to plant, animal and human biology. London:William Arnold; 1939.

\section{INVITATION TO SUBMIT PAPERS}

We would like to extend an invitation to all readers of The Journal of the Royal College of Physicians of Edinburgh to contribute original material, especially to the clinical section. The JRCPE is a peer-reviewed journal with a circulation of 8,000 . Its aim is to publish a range of clinical, educational and historical material of crossspecialty interest to the College's international membership.

The JRCPE is currently indexed in Embase, Google Scholar and the Directory of Open Access Journals, and the History section is included in Medline. The editorial team is keen to continue to improve both the quality of content and its relevance to clinical practice for Fellows and Members. All papers are subject to peer review and our turnaround time for a decision averages only eight weeks.

We would be pleased to consider submissions based on original clinical research, including pilot studies. The JRCPE is a particularly good forum for research performed

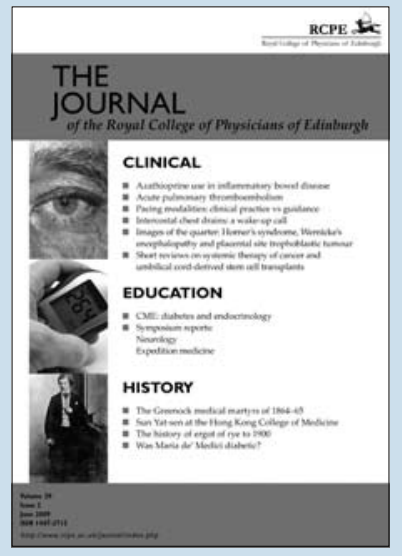
by junior doctors under consultant supervision. We would also consider clinical audits where the loop has been closed' and a demonstrable clinical benefit has resulted.

For further information about submissions, please visit: http://www.rcpe.ac.uk/journal/contributers.php or e-mail editorial@rcpe.ac.uk.Thank you for your interest in the College's journal.

The editorial team,

The Journal of the Royal College of Physicians of Edinburgh 